\title{
Functional inactivation of the IGF-I and insulin receptors in skeletal muscle causes type 2 diabetes
}

\author{
Ana M. Fernández, ${ }^{1}$ Jason K. Kim, ${ }^{3}$ Shoshana Yakar, ${ }^{1}$ Joëlle Dupont, ${ }^{1}$ Catalina Hernandez-Sanchez, ${ }^{1}$ \\ Arthur L. Castle, ${ }^{2}$ Jonathan Filmore, ${ }^{4}$ Gerald I. Shulman, ${ }^{3,4}$ and Derek Le Roith ${ }^{1,5}$ \\ ${ }^{1}$ Clinical Endocrinology Branch and ${ }^{2}$ Diabetes Branch, National Institute of Diabetes and Digestive and Kidney Diseases \\ (NIDDK), National Institutes of Health, Bethesda, Maryland 20892, USA; ${ }^{3}$ Howard Hughes Medical Institute \\ and the ${ }^{4}$ Department of Internal Medicine, Yale University School of Medicine, New Haven, Connecticut 06510, USA
}

Peripheral insulin resistance and impaired insulin action are the primary characteristics of type 2 diabetes. The first observable defect in this major disorder occurs in muscle, where glucose disposal in response to insulin is impaired. We have developed a transgenic mouse with a dominant-negative insulin-like growth factor-I receptor (KR-IGF-IR) specifically targeted to the skeletal muscle. Expression of KR-IGF-IR resulted in the formation of hybrid receptors between the mutant and the endogenous IGF-I and insulin receptors, thereby abrogating the normal function of these receptors and leading to insulin resistance. Pancreatic $\beta$-cell dysfunction developed at a relative early age, resulting in diabetes. These mice provide an excellent model to study the molecular mechanisms underlying the development of human type 2 diabetes.

[Key Words: IGF-I receptor; type 2 diabetes; insulin receptor; skeletal muscle; dominant-negative; transgenic]

Received April 30, 2001; revised version accepted June 14, 2001.

Type 2 diabetes is a life-threatening endocrine disorder that affects as many as $6 \%-10 \%$ of the population of the Western world (Kahn et al. 1996). The major cause of this disease is a progressive resistance to the actions of insulin in the peripheral tissues of the body, followed by a deterioration in insulin secretion (DeFronzo 1997). The first detectable defect in patients with type 2 diabetes is frequently the inability of muscle to respond to normal levels of circulating insulin (Lillioja et al. 1993; Kahn et al. 1996; DeFronzo 1997). Insulin resistance in both the periphery (primarily muscle and fat) and in the liver aggravates the altered carbohydrate and lipid metabolism. Under normal conditions, pancreatic $\beta$-cells secrete insulin in response to an elevation in blood glucose levels. To compensate for the insulin-resistant state, $\beta$-cells initially increase basal and postprandial insulin secretion (DeFronzo 1997). Eventually, $\beta$-cells can no longer compensate and fail to respond appropriately to the impairment in glucose disposal. Together, insulin resistance and loss of $\beta$-cell function eventually lead to the deterioration of glucose homeostasis and to the development of hyperglycemia.

Using gene-targeting technology, a number of useful

${ }^{5}$ Corresponding author.

E-MAIL Derek@helix.nih.gov; FAX (301) 480-4386.

Article and publication are at http://www.genesdev.org/cgi/doi/10.1101/ gad.908001. mouse models have recently been developed to study the progression of diabetes. Complete disruption of the insulin receptor $(I r)$ gene in mice leads to severe diabetes and death in the immediate postnatal period (Accili et al. 1996; Joshi et al. 1996). Although these results clearly demonstrate the importance of the Ir gene for normal physiological function, the resulting animals do not provide a useful model of the human diabetic state. Deletion of the Ir gene specifically in pancreatic $\beta$-cells resulted in mice with mild diabetes (Lauro et al. 1998; Kulkarni et al. 1999).

Because peripheral insulin resistance is often the first demonstrable change detected in states of impaired glucose tolerance, investigators have attempted to understand this abnormality by studying insulin-stimulated glucose metabolism in muscle, the organ that mediates most of this effect (Shulman et al. 1990). Muscle-specific Ir knockout mice (MIRKO) manifested moderate insulin resistance and a mild metabolic disorder, but did not develop either type 2 diabetes or any major metabolic changes (Bruning et al. 1998). Similarly, activation of the IR was substantially impaired in mice expressing a dominant-negative mutant Ir specifically in muscle, but these animals exhibited only mild insulin resistance /Chang et al. 1994). Lauro et al. (1999) observed a more profound alteration in insulin sensitivity, with impaired glucose tolerance, by crossing mice with a dominant-negative Ir transgene expressed in muscle and adipose tissue with Ir hemizygous gene-deleted mice. 
The lack of overt diabetes in mice with $I r$ defects in muscle could be explained by the normal function of the IR in other important tissues, namely, the pancreatic $\beta$-cells, liver, and fat. On the other hand, insulin-stimulated glucose uptake into specific muscle subgroups was not totally abolished, suggesting that insulin signaling may be mediated through an alternative pathway (Higaki et al. 1999; Wojtaszewski et al. 1999). The glucose transporter GLUT4 mediates insulin-induced glucose uptake in muscle and in other peripheral tissues. Interestingly, whereas Glut4-deficient mice failed to demonstrate diabetes (Katz et al. 1995), muscle-specific ablation of Glut4 resulted in severe insulin resistance and, in some mice, overt diabetes (Zisman et al. 2000). These findings are consistent with the important role played by GLUT4 in mediating the actions of insulin in peripheral target tissues (Zisman et al. 2000). Taken together, these studies suggest that type 2 diabetes has a heterogeneous etiology, and that mice with single genetic defects may not always provide useful models for studying the human disease states. Therefore, it is critical that other relevant animal models be developed to study this extremely important disease.

The IGF-I receptor (IGF-IR) represents another potential target to develop useful animal models for human diabetes. IGF-I and insulin are closely similar in both structure and function, and both can stimulate glucose uptake in muscle (Le Roith et al. 1995; Jullien et al. 1996; Frick et al. 2000). IGF-I is also a potential therapeutic tool, in that it has been shown to lower blood glucose in patients with insulin resistance, type 2 diabetes, and insulin-dependent diabetes mellitus (Kolaczynski and Caro 1994).

To determine directly whether IGF-IR plays an important role in glucose uptake by muscle and thereby controls glucose homeostasis, we generated mice overexpressing a dominant-negative IGF-IR specifically in skeletal muscle (MKR mice). Interestingly, these animals showed a striking loss of function of both the IGF-IR and the IR, as reflected in a marked decrease in glucose uptake upon stimulation with either IGF-I or insulin. Furthermore, these mice were insulin-resistant and rapidly developed overt diabetes, thereby providing an extremely useful model for the study of type 2 diabetes, its pathogenesis, and potential new therapies.

\section{Results}

Generation of transgenic mice overexpressing a dominant-negative IGF-I receptor specifically in skeletal muscle

The transgene MCK-KR-hIGF-IR (MKR) was used to generate seven independent lines of transgenic mice. Of these, five transmitted the transgene through their germline. Southern blot analysis revealed $\sim 12$ copies of the transgene, as compared to the endogenous IGF-IR (Fig. 1B). Analysis of mRNA levels using an RNase protection assay revealed strong expression of the mutant human IGF-IR that was restricted to skeletal muscle. The levels

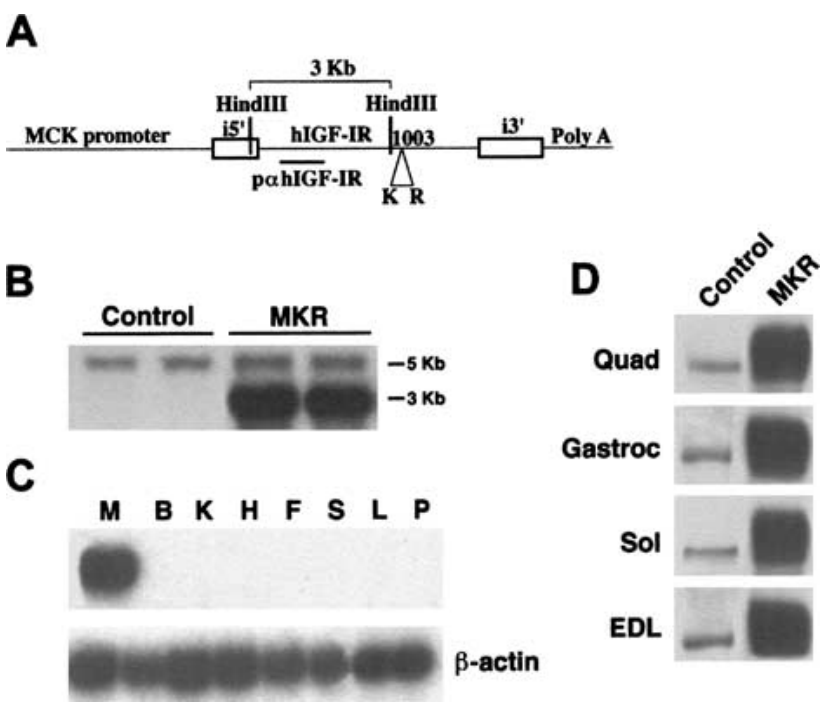

Figure 1. Gene-targeting and IGF-IR expression. (A) Schematic of the construct used to generate MKR mice. The mutant human IGF-IR cDNA (KR-IGF-IR) was fused downstream of the muscle-creatine kinase (MCK) promoter, as described in Materials and Methods. $(B)$ Southern blot analysis shows transmission of the transgene to the germline. The probe, $p$ - $\alpha$-IGF-IR, detects both the endogenous IGF-IR and the transgene, as described. Digestion with HindIII generated 5-kb and 3-kb bands, as shown. The number of copies of the transgene was approximately 5-12-fold higher than that of the endogenous IGF-IR. (C) mRNA expression of the IGF-IR is highly enriched in skeletal muscle of the MKR mice. M, skeletal muscle; B, brain; $\mathrm{K}$, kidney; H, heart; F, white fat; S, spleen; L, liver; P, pancreas. $(D)$ Expression of the IGF-IR protein is highly enriched in various skeletal muscles of MKR mice. A representative Western blot showing IGF-IR immunoreactivity levels in muscle extracts from MKR and wild-type (Control) mice. Quad, quadriceps; Gastroc, gastrocnemius; Sol, soleus; EDL, extensor digitorum longus. Blots are representative of those obtained in three independent experiments performed on at least five animals of each genotype.

were increased approximately ninefold above that of the endogenous mouse IGF-IR. We also found weak levels of expression in cardiac muscle in two lines that were not included in this study (data not shown). No mRNA was detected in a variety of other tissues tested (Fig. 1C). There were no differences in the endogenous levels of IGF-IR between MKR and wild-type (control) mice, as determined by RNase protection assays (data not shown). Immunoblot analysis showed a corresponding increase $(\sim 10$-fold) in the level of transgenic hIGF-IR protein in various muscles (Fig. 1D). The data shown here are derived from male mice in one line of mice; identical results were found in a second mouse line. Male and female mice displayed qualitatively the same results in all the experiments performed in this study. MKR mice showed a modest retardation in growth rate from birth to the age of $4 \mathrm{wk}(20 \%$ reduction in body weight, $P<0.01)$, and a smaller reduction in growth from this age through adulthood $(10 \%$ reduction in body weight, $P<0.05)$, as compared to control animals (data not shown). 
Overexpression of a dominant-negative IGF-IR impairs both IGF-I and insulin signaling in skeletal muscle

To determine the functional effect of overexpression of the dominant-negative mutant hIGF-IR in skeletal muscle, we compared the early IGF-I signaling events in adult MKR and wild-type mice. Systemic infusion of IGF-I induced tyrosine phosphorylation of both the IGFIR $\beta$-subunit and IRS-1 in skeletal muscle of wild-type mice. These effects were completely abolished in skeletal muscle from MKR mice (Fig. 2A). The association of p85 with IRS-1 was markedly reduced in the skeletal muscle of MKR animals as compared to wild-type mice (Fig. 2A). There was, however, no difference in immunoreactivity levels of IRS-1 or p85 between wild-type and MKR mice (Fig. 2A).

The IR and IGF-IR share many of the same signaling pathways. To determine whether overexpression of the dominant-negative IGF-IR affected the function of the IR, we also evaluated the IR signaling pathway in MKR versus wild-type mice. Insulin-induced tyrosine phosphorylation of both IR and IRS-1 were dramatically reduced by $\sim 85 \%$ in MKR mice (Fig. 2B). Similarly, the association of $\mathrm{p} 85$ with IRS-1 was also reduced in MKR mice. Overall levels of IR, IRS-1, and p85 immunoreactivity were equal in muscle derived from MKR and wildtype animals (Fig. 2B). Taken together, these data demonstrate that the expression of a dominant-negative KRIGF-IR in muscle impairs the function of both the IGF-IR and the IR in vivo, as reflected by attenuation of their signaling cascades.

\section{Hybrid receptor formation in MKR mice}

It has been demonstrated that hybrid receptors can form in tissues expressing both the IGF-IR and the IR, that is, one IGF-I hemireceptor and one insulin hemireceptor can dimerize (Lauro et al. 1999). In view of the finding that overexpression of the KR-IGF-IR can impair signaling through both the IGF-IR and IR signaling pathways, we explored the possibility that the mutant IGF-IR and endogenous IR may form hybrid receptors. We found that IR immunoreactivity was coimmunoprecipitated with the IGF-IR in protein extracts from hindlimb muscle of MKR mice. As shown in Figure 3, A and B, significant amounts of IR were detected in the IGF-IR immunoprecipitates and vice versa. Densitometric analysis revealed a 7.5-fold increase in the amount of IR coimmunoprecipitated with the IGF-IR immunoprecipitates in MKR mice, as compared to control mice. Similarly, sixfold higher levels of IGF-IRs were detected in the IR immunoprecipitates from MKR mice, as compared to control mice. Neither systemic infusion of insulin nor of IGF-I activated the hybrid receptors (Fig. $3 \mathrm{C}, \mathrm{D})$. Taken together, these data suggest that overexpression of a dominant-negative hIGF-IR in skeletal muscle induced the formation of nonfunctioning hybrids between the mutant and the endogenous IGF-IRs and IRs.

\section{Impaired glucose uptake and glucose homeostasis in $M K R$ mice}

To explore the consequence of reduced IGF-I and insulin signaling in skeletal muscle, we measured in vitro glucose uptake in extensor digitorum longus (EDL) muscle, the main glycolytic muscle from adult mice. As shown in Figure 4A, insulin stimulated glucose uptake in EDL muscle by fivefold above basal levels in wild-type mice but only by 1.5 -fold in EDL muscle from MKR mice. Wild-type animals showed a fourfold increase in glucose uptake in EDL muscle following IGF-I stimulation, whereas there was no response to IGF-I in muscle from MKR mice (Fig. 4B). There were no differences in GLUT4
Figure 2. IGF-I and insulin-stimulated signaling are abolished in MKR muscle. $(A)$ Seven- to 12-week-old control and MKR mice were infused with either saline (-) or $1 \mathrm{mg} / \mathrm{kg}$ rhIGF-I $(+)$ via the inferior vena cava after overnight starvation. Hindlimb muscles were homogenized and subjected to immunoprecipitation of the IGF-IR (upper panels), IRS-1 (middle panels), followed by Western blotting with anti-phosphotyrosine antibody, IGF-IR antibody, IRS-1 antibody, or an antibody to p85. (Bottom panel) A Western blot analysis on the same extracts using an anti-p85 antibody. (B) The experiment was performed as described in $A$ with the exception that animals were infused with $5 \mathrm{U}$ of insulin and an anti-IR was used to determine IR phosphorylation and levels of expression. Blots for both $A$ and $B$ are representative of three independent experiments performed on at least five animals under each condition.
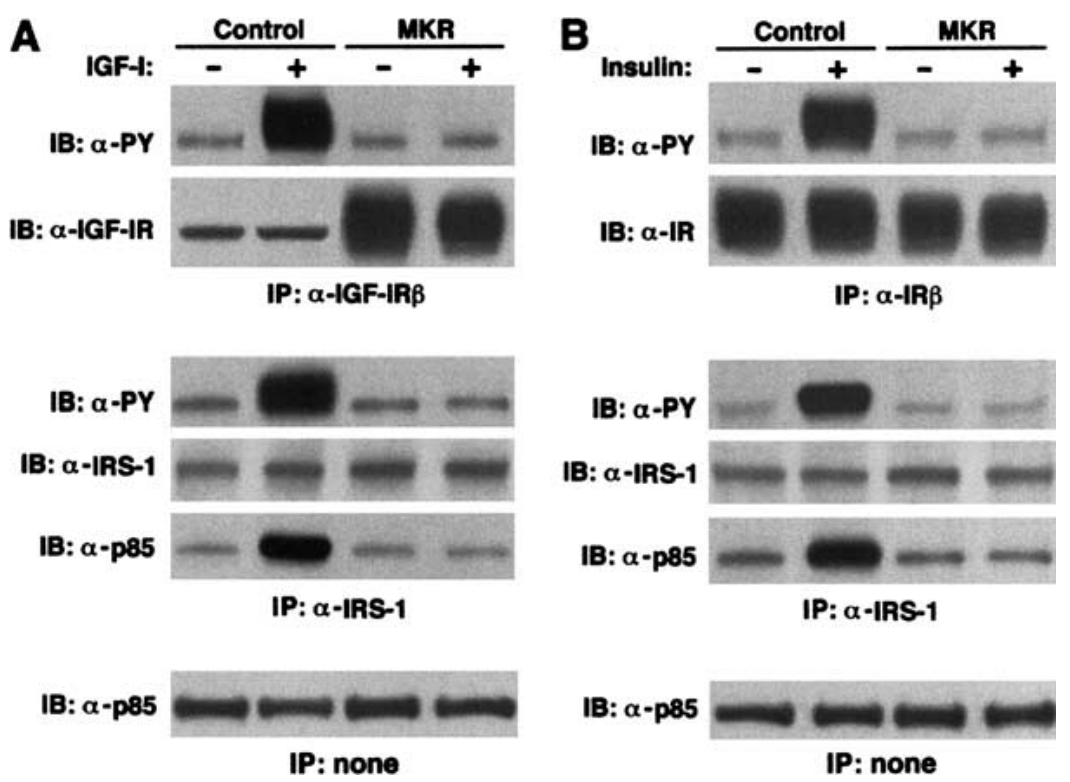
A

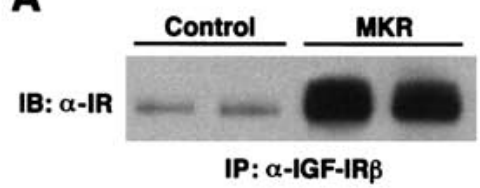

C

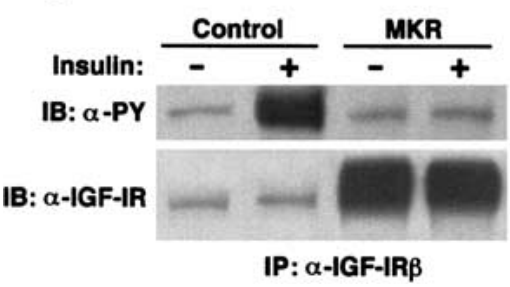

B

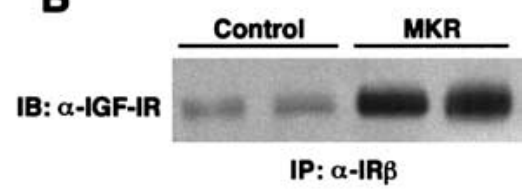

D

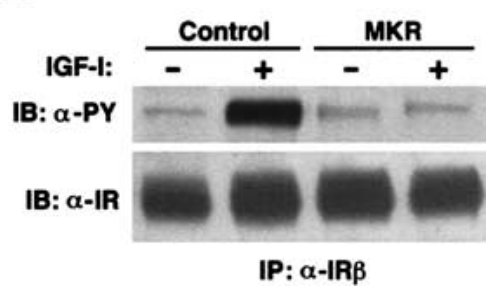

Figure 3. Assessment of hybrid receptor formation in MKR mice. (A) The IGF-IR was immunoprecipitated (IP) from protein extracts of hindlimb muscles from either control (wildtype) or MKR mice. The resulting samples were subjected to immunoblotting with an anti-IR antibody. $(B)$ In the reverse experiment of that shown in $A$, the IGF-IR was immunoprecipitated (IP) from protein extracts of hindlimb muscles from either control (wild-type) or MKR mice. The resulting samples were subjected to immunoblotting with an anti-IGF-IR antibody. The results shown are representative of those obtained in three similar experiments. $(C)$ Control and MKR mice were infused with either saline $(-)$ or insulin $(+)$, as described. The IGF-IR was then immunoprecipitated (IP) from protein extracts of hindlimb muscles and subjected to immunoblotting with either an anti-PY or anti-IGF-IR antibody, as shown. $(D)$ Control and MKR mice were infused with either saline $(-)$ or IGF-I (+), as described. The IR was then immunoprecipitated (IP) from protein extracts of hindlimb muscles and subjected to immunoblotting with either an anti-PY or an anti-IR antibody, as shown.

immunoreactivity levels in whole muscle extracts from the two groups of animals (data not shown). Therefore, the defects seen in glucose uptake after insulin or IGF-I stimulation were not caused by down-regulation of GLUT4, the main insulin-stimulated glucose transporter in muscle. In vivo insulin tolerance tests performed at this age demonstrated that MKR mice were insulin-resistant, as compared to wild-type mice (Fig. 4C).

To determine at what age the muscle insulin resistance affected whole-body glucose homeostasis, we monitored blood glucose concentrations and serum insulin levels in MKR and wild-type mice from 2 to $8 \mathrm{wk}$ of age. MKR mice displayed hyperinsulinemia as early as 2 wk of age (Fig. 5A); however, fed glucose levels did not increase until $5 \mathrm{wk}$ of age (Fig. 5B). Similar changes in insulin and glucose levels were seen in the fasted state (data not shown). Glucose-tolerance tests performed at 3-4 wk showed that MKR mice have normal fasting glucose, with mildly elevated glucose levels at 15,30, and $60 \mathrm{~min}$ in MKR mice, as compared to wild-type mice (Fig. 5C). In contrast, at 7-12 wk the glucose tolerance in MKR mice was clearly abnormal (Fig. 5D).

\section{Metabolic responses in MKR mice in the prediabetic state}

To examine the effect of insulin resistance in the prediabetic state, we analyzed insulin-induced glucose metabolism and glucose tolerance in vivo with a hyperinsulinemic-euglycemic clamp. At 3-4 wk of age, basal plasma insulin levels were elevated (Fig. 5A) and blood glucose levels were normal in MKR mice (Table 1; Fig. 5B), suggesting that insulin resistance is present. During the clamp, insulin was infused at a rate of $2.5 \mathrm{mU} / \mathrm{kg}$ per min and plasma glucose levels were clamped at between 113 and $125 \mathrm{mg} / \mathrm{dL}$ in both groups. The rate of glucose infusion required to maintain euglycemia was markedly lower in the MKR mice (Table 1). Total body glucose disposal, glycolysis, and glycogen synthesis were significantly reduced in the MKR mice, as compared to wildtype mice (Table 2). Hepatic glucose output was suppressed in wild-type mice, but unaffected in the MKR mice (Table 1). In skeletal muscle and brown adipose tissue (BAT), glucose transport activity was reduced by $\sim 50 \%$ in the MKR mice, as compared to wild-type mice (Table 2). Morphologically, no notable differences were observed between the livers of adult MKR and wild-type mice (as determined by H\&E staining; data not shown). However, significant differences were revealed after metabolically staining for PAS, where a marked increase in the number of glycogen deposits was observed in MKR mice as compared to wild-type mice (data not shown).

\section{$\beta$-Cell function in MKR mice}

To determine whether the onset of diabetes is associated with an abnormality in pancreatic insulin secretion, we evaluated pancreatic $\beta$-cell function. At 3-4 wk, MKR mice had elevated basal insulin levels and responded to glucose challenge with an acute rise in serum insulin levels in a manner similar to wild-type mice (Fig. 5E). At 7-12 wk, MKR mice showed no response to the acute glucose load (Fig. 5F), strongly suggesting that $\beta$-cell dysfunction is most likely the cause of the appearance of diabetes in the MKR mice. Both control and MKR mice showed a threefold increase in acute insulin release in response to arginine (data not shown). Therefore, MKR mice show a loss of acute first-phase insulin release that is specific to glucose. $\mathrm{H} \& \mathrm{E}$ staining demonstrated islet cell hyperplasia in MKR mice compared to wild-type mice, consistent with a response to insulin resistance (data not shown).

\section{Changes in lipid metabolism in MKR mice}

Serum free fatty acids and triglycerides were $\sim$ twofold higher in the MKR mice compared to wild-type mice in 

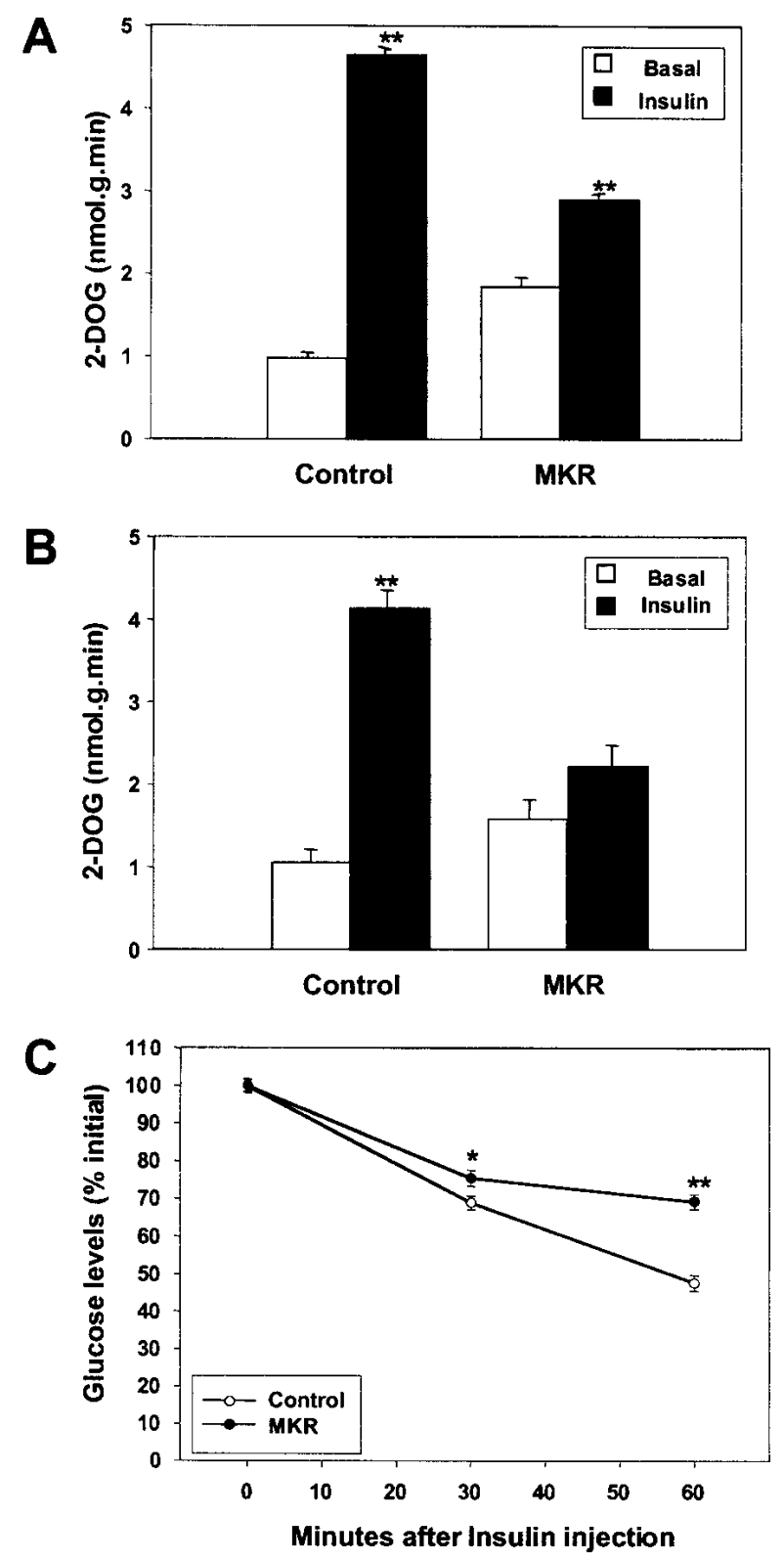

Figure 4. Impairment of glucose uptake in isolated skeletal muscle in MKR mice leads to insulin resistance. Glucose uptake was evaluated in EDL muscles from 7-12-week-old control (wild-type) and MKR mice, as described in Materials and Methods. EDL muscle was untreated (open bars) or stimulated (closed bars) with either (A) $70 \mathrm{nM}$ insulin or (B) $500 \mathrm{nM}$ rhIGF-I, as shown. Results are representative of those obtained in three independent experiments including six mice in each group. $\left(^{\star \star}\right)$ $P<0.01$. (C) Serum glucose levels were measured at times 0 $\mathrm{min}, 30 \mathrm{~min}$, and $60 \mathrm{~min}$ after a peritoneal injection of insulin in either wild-type (open circles) or MKR mice (closed circles). $\left(^{\star}\right) P<0.05 ;\left(^{\star \star}\right) P<0.01$.

both 3-4-week-old and adult mice (Table 3). Moreover, triglyceride measurements in liver also showed a twofold elevation in the MKR mice (Table 3). These findings are also consistent with an aggravation of the insulinresistant state in insulin-sensitive tissues of the MKR mice.

\section{Discussion}

Type 2 diabetes arises from a heterogeneous etiology, with secondary effects from environmental influences. Although insulin resistance is a characteristic feature of type 2 diabetes, a concomitant abnormality in pancreatic insulin secretion is thought to be an integral component of the diabetic syndrome. A number of approaches to evaluate the function of the IR in specific tissues have now been developed. Overexpression of a dominantnegative IR under the control of a muscle creatine kinase (MCK) promoter/enhancer abrogated the function of the endogenous muscle IR (Chang et al. 1994). In another study, the Ir gene was deleted specifically in muscle by the cre/loxP system (Bruning et al. 1998). Each of these two mouse models exhibited insulin resistance in vitro, but the mice did not develop marked hyperinsulinemia or diabetes. These studies suggested that tissues other than muscle may play an important role in insulin-regulated glucose disposal. This idea is consistent with the hypothesis that mice store a larger percentage of glycogen in liver than in muscle, as compared to humans (Lauro et al. 1998). To study the role of other tissues in the pathogenesis of type 2 diabetes, Kahn and co-workers independently deleted the Ir gene in pancreatic $\beta$-cells and in liver (Kulkarni et al. 1999; Michael et al. 2000). These mice showed clear metabolic abnormalities, but neither mouse model developed diabetes. Furthermore, mice with targeted impairment of insulin action in both muscle and adipose tissue (Lauro et al. 1998) also failed to develop diabetes.

We hypothesized that the lack of diabetes in mice with an inactivated IR in muscle was due to compensatory actions of the IGF-IR, which, like the IR, stimulates glucose uptake by GLUT4 (Jullien et al. 1996; Frick et al. 2000). Indeed, mice with a muscle-specific deletion of Glut4 developed severe insulin resistance, fasting hyperglycemia, and glucose intolerance (Zisman et al. 2000). We therefore set out to study the effects of muscle-specific functional blockade of the IGF-IR on glucose homeostasis.

Expression of a dominant-negative mutant IGF-IR resulted in a marked reduction in IGF-I-mediated glucose uptake into skeletal muscle. This paralleled the absence of IGF-I-induced tyrosine phosphorylation of the IGF-IR and IRS-1 in muscle. One possible mechanism by which this dominant-negative effect may be mediated is by the formation of hybrid receptors (Frattali et al. 1992; Moxham and Jacobs 1992). Using coimmunoprecipitations, we demonstrated that nonfunctional hybrids form between the mutant human IGF-IR and the endogenous mouse IGF-IRs and IRs. Because the mutant hemireceptor fails to become autophosphorylated, transphosphorylation of the endogenous mouse hemireceptor cannot occur, thereby resulting in functional inactivation of both receptor types and markedly reducing insulin-induced glucose uptake into muscle in MKR mice. In contrast, hybrid receptors were not detected in the transgenic model of Moller and coworkers, and only small amounts of hybrid receptors were formed in the model of the 

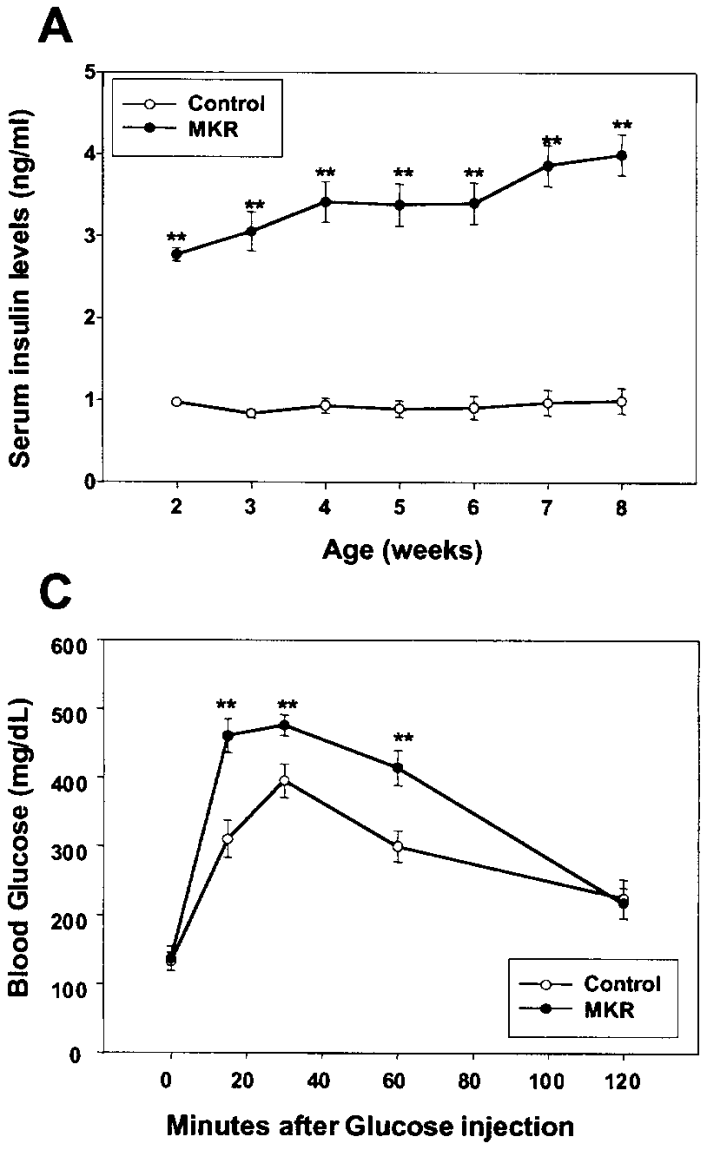

B

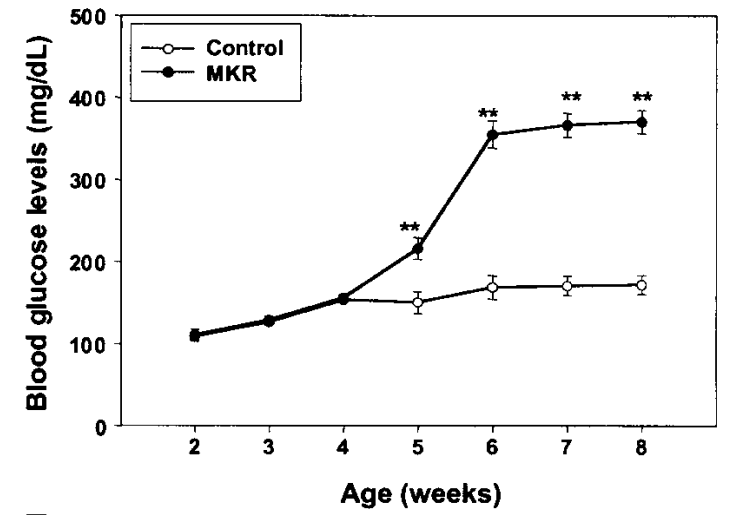

$\mathbf{D}$

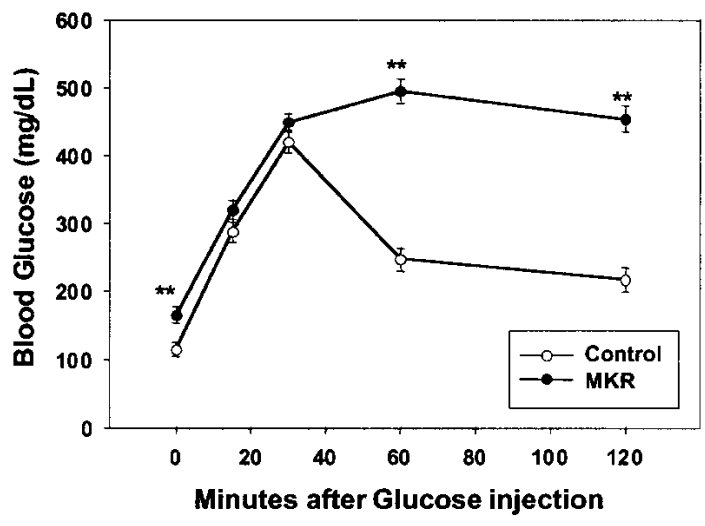

$E$
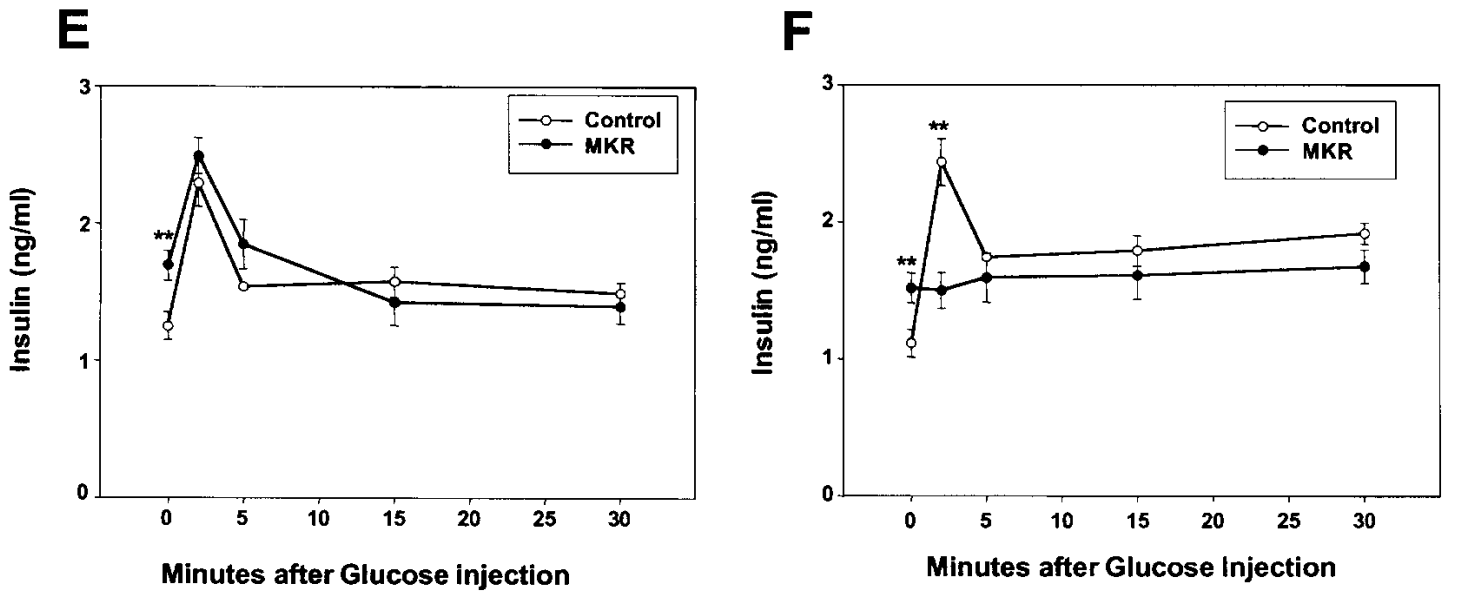

Figure 5. Metabolic and $\beta$-cell disturbances in MKR mice during postnatal stages. $(A)$ Insulin and $(B)$ glucose levels were determined from blood samples obtained from fed MKR (closed circles) and control (wild-type) mice (open circles) from 2 to 8 wk of age. Data represent the mean \pm SEM from at least 20 animals in each group. $\left(^{\star \star}\right) P<0.01$. Glucose tolerance tests were performed on fasted mice after an i.p. injection of $2 \mathrm{~g} / \mathrm{kg}$ glucose at either $(C)$ 3-4 wk of age or $(D)$ 8-12 wk of age. Blood glucose concentrations were determined on blood samples obtained by tail biopsy at the indicated times. Results are expressed as average blood glucose level \pm SEM of 10 animals of each group. $\left.{ }^{\star \star}\right) P<0.01$. To examine $\beta$-cell function, glucose $(3 \mathrm{~g} / \mathrm{kg})$ was injected intraperitoneally in fasted, $(E)$ young (3-4-wk) and (F) adult (7-12-wk) mice. Blood samples were collected from tail biopsies from MKR (closed circles) and wild-type (open circles) mice at the indicated time intervals. Insulin levels were determined by RIA. Values shown represent mean \pm SEM of 10 animals of each group. $\left(^{\star \star}\right) P<0.01$.

Lauro group (Chang et al. 1994; Lauro et al. 1998). The formation of heterodimeric mutant receptors therefore provides a mechanism to explain the onset of a more severe form of insulin resistance in the MKR mice. Similarly, increased expression of insulin/IGF-I hybrid receptors has been reported in the skeletal muscle of patients 
Table 1. Metabolic parameters during basal and hyperinsulinemic-euglycaemic clamp periods in control and MKR mice

\begin{tabular}{|c|c|c|c|c|c|c|c|}
\hline & \multirow[b]{2}{*}{$\begin{array}{l}\text { Mice } \\
(n)\end{array}$} & \multicolumn{3}{|c|}{ Basal period } & \multicolumn{3}{|c|}{ Clamp period } \\
\hline & & $\begin{array}{l}\text { Body weight } \\
(\mathrm{g})\end{array}$ & $\begin{array}{l}\text { Plasma glucose } \\
\qquad(\mathrm{mg} / \mathrm{dL})\end{array}$ & $\begin{array}{c}\text { Hepatic glucose } \\
\text { output } \\
\text { (umole/kg per min) }\end{array}$ & $\begin{array}{l}\text { Plasma glucose } \\
\qquad(\mathrm{mg} / \mathrm{dL})\end{array}$ & $\begin{array}{l}\text { Glucose infusion } \\
\text { (umole/kg per min) }\end{array}$ & $\begin{array}{c}\text { Hepatic glucose } \\
\text { output } \\
\text { (umole/kg per min) }\end{array}$ \\
\hline Control & 7 & $15 \pm 1$ & $137 \pm 1$ & $15.2 \pm 1.6$ & $113 \pm 11$ & $84.6 \pm 5.4$ & $2.9 \pm 1.3$ \\
\hline MKR & 7 & $13 \pm 1^{\mathrm{a}}$ & $140 \pm 2$ & $19.9 \pm 2.8$ & $125 \pm 12$ & $29.4 \pm 8.5^{\mathrm{b}}$ & $14.3 \pm 3.6^{\mathrm{b}}$ \\
\hline
\end{tabular}

Data represent the mean \pm SEM.

${ }^{\mathrm{a}} P<0.05$ versus control.

${ }^{\mathrm{b}} P<0.01$ versus control.

with type 2 diabetes, and this was positively correlated with severe insulin resistance (Federici et al. 1996, 1998).

The most surprising finding of the present study is that the MKR mice develop diabetes at a young age (as early as $5 \mathrm{wk}$ ). This is in striking contrast to most other mouse models, in which the mice typically develop diabetes at a much later age, if at all. Until $4 \mathrm{wk}$ of age, hyperinsulinemia was seen in both fasting and fed states. However fasting glucose levels were normal in MKR mice, suggesting insulin resistance with compensation by the pancreatic $\beta$-cells. After $4 \mathrm{wk}$, plasma glucose levels became elevated and overt diabetes was seen. This finding was surprising in view of the previous mouse models that failed to develop diabetes, including deletion of $I r$ in muscle (MIRKO) or functional inhibition of IR by overexpressing a dominant-negative IR specifically in muscle (Chang et al. 1994; Bruning et al. 1998). One possible interpretation, which we favor, is that the remaining IGF-IRs compensated for the loss of IR function in these mice. It is of interest to note that the phenotype of MKR mice is similar to that of mice with a musclespecific deletion of GLUT4, which exhibited severe insulin resistance, fasting hyperglycemia, and glucose intolerance (Zisman et al. 2000). Because GLUT4 is a downstream target of the IR and of the IGF-IR, these studies suggest that disruption of both the receptors (IGF-IR and IR) or of the GLUT4 signaling pathway in muscle can lead to a diabetic phenotype. In contrast, disruption of the IR signaling pathway in muscle can be functionally compensated by the IGF-IR.

We further propose that the defects in the pancreatic $\beta$-cells and in insulin secretion in MKR mice could contribute to their abnormally high levels of glucose and the early onset of a diabetic phenotype. In summary, the MKR model mouse represents an important new animal model that can be used to study human type 2 diabetes. Further characterization of these animals may improve our understanding of the cellular and molecular changes that occur in type 2 diabetes, and thereby lead to the development of better therapies for this common disorder.

\section{Materials and methods}

Generation of skeletal muscle-specific dominant-negative IGF-IR transgenic mice

PCR mutagenesis was used to generate the pBSKR-hIGF-IR vector (Fig. 1A). The lys $1003 \rightarrow$ arg 1003 mutation abolishes ATPbinding within the $\beta$-subunit of the human IGF-IR cDNA (KR mutant), as described previously (Kato et al. 1993). To achieve high levels of expression we used a pGEM11-hybrid intron cassette vector (Choi et al. 1991). The KR-hIGF-IR cDNA was excised with EcoRI/BamHI. The resulting insert was blunt-ended and ligated into the unique EcoRV site of the pGEM11-hybrid intron vector, resulting in pGEM11-intron-KR-hIGF-IR.

The promoter of the muscle creatine kinase (MCK) gene was used to specifically express KR-hIGF-IR in skeletal muscle. A pBSMCK vector (kindly provided by C.R. Kahn, Boston, MA) consisting of a $6.5-\mathrm{kb}$ fragment of the MCK gene contained the 5 '-flanking region of the MCK promoter and enhancer 1, exon 1 (noncoding), the first intron/enhancer 2, and the first $16 \mathrm{bp}$ of exon 2. The intron-flanked KR-hIGF-IR was liberated from pGEM11 with NotI and subcloned downstream of the MCK promoter to result in pBSMCK-KR-hIGF-IR. The transgene MCK-KR-hIGF-IR (MKR) (Fig. 1A) was excised from the parental plasmid with PvuII/SacI, purified by agarose gel electrophoresis, and microinjected into fertilized eggs from $\mathrm{FVB} / \mathrm{N}$ mice. These eggs were implanted into CD-1 foster mothers, and the integration of the transgene in the offspring was assessed by Southern blot analysis.

Table 2. Whole-body, skeletal muscle, and brown adipose tissue glucose transport and metabolism

\begin{tabular}{|c|c|c|c|c|c|}
\hline & \multicolumn{2}{|c|}{ Glucose transport } & \multicolumn{3}{|c|}{ Whole body glucose flux } \\
\hline & $\begin{array}{c}\text { Muscle } \\
(\mu \mathrm{mole} / \mathrm{kg} \text { per min) }\end{array}$ & $\begin{array}{c}\text { Brown adipose tissue } \\
\text { ( } \mu \text { mole/kg per min) }\end{array}$ & $\begin{array}{l}\text { Whole body glucose uptake } \\
\text { (mg/kg per min) }\end{array}$ & $\begin{array}{c}\text { Glycolysis } \\
\text { (mg/kg per } \mathrm{min})\end{array}$ & $\begin{array}{l}\text { Glycogen synthesis } \\
\text { (mg/kg per min) }\end{array}$ \\
\hline Control & $299 \pm 33$ & $1123 \pm 254$ & $87.6 \pm 5.2$ & $46.4 \pm 3.6$ & $41.2 \pm 6.2$ \\
\hline $\mathrm{MKR}^{\mathrm{a}}$ & $162 \pm 31$ & $540 \pm 88$ & $43.7 \pm 5.8$ & $31.5 \pm 4.1$ & $12.2 \pm 3.3$ \\
\hline
\end{tabular}

Data represent the mean \pm SEM.

${ }^{\mathrm{a}} P<0.01$ versus control. 
Table 3. Lipid metabolism in the MKR mice

\begin{tabular}{|c|c|c|c|c|}
\hline & \multicolumn{2}{|c|}{ Young mice } & \multicolumn{2}{|c|}{ Adult mice } \\
\hline & Control & $\mathrm{MKR}^{\mathrm{a}}$ & Control & $\mathrm{MKR}^{\mathrm{a}}$ \\
\hline Free fatty acids (nmole $/ \mu \mathrm{L})$ & $0.4 \pm 0.1$ & $1 \pm 0.2$ & $0.5 \pm 0.1$ & $1.1 \pm 0.1$ \\
\hline Triglycerides (mg/dL) & $68.3 \pm 5.2$ & $142.3 \pm 4.6$ & $70.2 \pm 8.2$ & $145.7 \pm 9.1$ \\
\hline Liver triglycerides ( $\mu$ mole/g) & $10.9 \pm 0.6$ & $24.1 \pm 0.6$ & $8.3 \pm 0.2$ & $16.8 \pm 0.2$ \\
\hline
\end{tabular}

Data represent the mean \pm SEM.

${ }^{\mathrm{a}} \mathrm{P}<0.01$ versus control.

\section{Animals and genotyping}

Mice were kept under a 12-h light/dark cycle and were fed standard diets. All studies were conducted in accordance with NIH guidelines as approved by the Animal Care and Use Committee of the National Institute of Diabetes and Digestive and Kidney Diseases (NIDDK). Founder mice were backcrossed with FVB/N mice to generate transgenic offspring. All studies were conducted on both hemizygous and homozygous transgenic mice. Controls consisted of age- and sex-matched wild-type littermates. To identify the transgene we performed Southern blot analysis on tail DNA of 3-week-old mice using a probe $(\mathrm{p}-\alpha-$ hIGF-IR) that consisted of 379 bp coding for part of the $\alpha$-subunit of the human IGF-IR cDNA (Ota et al. 1989).

\section{Solution hybridization/RNase protection assay analysis}

Tissues were homogenized in Trizol reagent (GIBCO), and total RNA was isolated as recommended by the manufacturer. Total RNA $(20 \mu \mathrm{g})$ was hybridized with a ${ }^{32} \mathrm{P}$-labeled riboprobe specific for the $\alpha$-hIGF-IR, the $\alpha$-mIGF-IR, and for $\beta$-actin mRNA (Ambion). RNase protection assays were performed exactly as described previously (Yakar et al. 1999).

\section{Insulin and IGF-I treatment}

Experiments were carried out in mice fasted overnight. Animals were anesthetized with Avertin (15 mL/kg body weight) intraperitoneally (i.p.). rhIGF-I (1 mg/kg; a kind gift of Genentech) or rhInsulin (5U/animal; Sigma) was administered through the inferior vena cava.

\section{Immunoprecipitations and immunoblotting analysis}

At the indicated times after treatment with IGF-I or insulin, tissues were rapidly removed from anesthetized mice and processed for immunoprecipitations and immunoblotting exactly as described previously (Dupont et al. 1998).

\section{Analytical assays}

Blood glucose levels were determined from the mouse tail vein using a glucometer (One Touch II, Lifescan). Serum insulin levels were determined in samples taken from the retro-orbital venous cavity using a radioimmunoassay kit with rat insulin as a standard (Linco, St. Louis, MO). Both measurements were performed in fasted and fed animals. FFA and triglyceride levels were analyzed in serum from fasted mice using a commercial FFA kit (Boehringer Mannheim) and the GPO-Trinder kit (Sigma), respectively. Liver triglycerides were measured in fasted mice using a modified method from Burant et al. (1997). Insulin and glucose tolerance tests were performed in fasted animals after i.p. injections of either insulin $(0.5 \mathrm{U} / \mathrm{kg}$ body weight) or glucose ( $2 \mathrm{~g} / \mathrm{kg}$ body weight). Blood glucose values were measured immediately before and 30 and $60 \mathrm{~min}$ after insulin injection, and before and 15, 30, 60, and 120 min after glucose injection. For insulin release, either glucose $(3 \mathrm{~g} / \mathrm{kg}$ body weight) or L-arginine (10 nM/L in $0.2 \mathrm{M} \mathrm{PBS}$ ) was injected i.p. into mice that were fasted overnight. Blood from the tail vein was collected at $0,2,15$, and $30 \mathrm{~min}$ after injection in heparinized capillaries and centrifuged. Insulin levels in plasma were measured as described above.

\section{Glucose uptake in isolated muscles}

Glucose uptake in isolated muscle was performed using $70 \mathrm{nM}$ insulin and $500 \mathrm{nM}$ rhIGF-I, as described previously (Lauro et al. 1998).

Insulin-stimulated whole body and tissue glucose flux (hyperinsulinemic-euglycemic clamp)

These experiments were performed in overnight fasted mice, exactly as described previously (Kim et al. 2000).

\section{Statistical analysis}

Results are expressed as the mean \pm SEM. Statistical analysis of the data was performed using a one factor ANOVA followed by a $t$-test.

\section{Acknowledgments}

We thank Marc Reitman for critical evaluation of the manuscript, Oksana Gavrilova for helpful comments, and Dana Beitner-Johnson for editing the manuscript. We also acknowledge B. Samuels for insulin radioimmunoassays, B. Stannard for technical assistance, C.R. Kahn for providing the MCK promoter, and S. Cushman for providing the GLUT4 antiserum. A.M.F. was supported by a postdoctoral fellowship of the Ministerio de Educación y Cultura of Spain. J.K.K. is a research associate and G.I.S. is an investigator of the Howard Hughes Medical Institute.

The publication costs of this article were defrayed in part by payment of page charges. This article must therefore be hereby marked "advertisement" in accordance with 18 USC section 1734 solely to indicate this fact.

\section{References}

Accili, D., Drago, J., Lee, E.J., Johnson, M.D., Cool, M.H., Salvatore, P., Asico, L.D., Jose, P.A., Taylor, S.I., and Westphal, H. 1996. Early neonatal death in mice homozygous for a null allele of the insulin receptor gene. Nat. Genet. 12: 106-109.

Bruning, J.C., Michael, M.D., Winnay, J.N., Hayashi, T., Horsch, D., Accili, D., Goodyear, L.J., and Kahn, C.R. 1998. A muscle-specific insulin receptor knockout exhibits features of the metabolic syndrome of NIDDM without altering 
glucose tolerance. Mol. Cell 2: 559-569.

Burant, C.F., Sreenan, S., Hirano, K., Tai, T.A., Lohmiller, J., Lukens, J., Davidson, N.O., Ross, S., and Graves, R.A. 1997. Troglitazone action is independent of adipose tissue. J. Clin. Invest. 100: 2900-2908.

Chang, P.Y., Benecke, H., Le Marchand-Brustel, Y., Lawitts, J., and Moller, D.E. 1994. Expression of a dominant-negative mutant human insulin receptor in the muscle of transgenic mice. J. Biol. Chem. 269: 16034-16040.

Choi, T., Huang, M., Gorman, C., and Jaenisch, R. 1991. A generic intron increases gene expression in transgenic mice. Mol. Cell. Biol. 11: 3070-3074.

DeFronzo, R.A. 1997. Pathogenesis of type 2 diabetes: Metabolic and molecular implications for identifying diabetes genes. Diabetes Rev. 5: 177-269.

Dupont, J., Derouet, M., Simon, J., and Taouis, M. 1998. Nutritional state regulates insulin receptor and IRS-1 phosphorylation and expression in chicken. Am. J. Physiol. 274: E309E316.

Federici, M., Zucaro, L., Porzio, O., Massoud, R., Borboni, P., Lauro, D., and Sesti, G. 1996. Increased expression of insulin/insulin-like growth factor-I hybrid receptors in skeletal muscle of noninsulin-dependent diabetes mellitus subjects. J. Clin. Invest. 98: 2887-2893.

Federici, M., Lauro, D., D'Adamo, M., Giovannone, B., Porzio, O., Mellozzi, M., Tamburrano, G., Sbraccia, P., and Sesti, G. 1998. Expression of insulin/IGF-I hybrid receptors is increased in skeletal muscle of patients with chronic primary hyperinsulinemia. Diabetes 47: 87-92.

Frattali, A.L., Treadway, J.L., and Pessin, J.E. 1992. Insulin/ IGF-1 hybrid receptors: Implications for the dominant-negative phenotype in syndromes of insulin resistance. J. Cell Biochem. 48: 43-50.

Frick, F., Oscarsson, J., Vikman-Adolfsson, K., Ottosson, M., Yoshida, N., and Eden, S. 2000. Different effects of IGF-I on insulin-stimulated glucose uptake in adipose tissue and skeletal muscle. Am. J. Physiol. Endocrinol. Metab. 278: E729E737.

Higaki, Y., Wojtaszewski, J.F., Hirshman, M.F., Withers, D.J., Towery, H., White, M.F., and Goodyear, L.J. 1999. Insulin receptor substrate- 2 is not necessary for insulin- and exercise- stimulated glucose transport in skeletal muscle. J. Biol. Chem. 274: 20791-20795.

Joshi, R.L., Lamothe, B., Cordonnier, N., Mesbah, K., Monthioux, E., Jami, J., and Bucchini, D. 1996. Targeted disruption of the insulin receptor gene in the mouse results in neonatal lethality. EMBO J. 15: 1542-1547.

Jullien, D., Heydrick, S.J., Gautier, N., Van Obberghen, E., and Le Marchand-Brustel, Y. 1996. Effect of IGF-I on phosphatidylinositol 3-kinase in soleus muscle of lean and insulinresistant obese mice. Diabetes 45: 869-875.

Kahn, C.R., Vicent, D., and Doria, A. 1996. Genetics of noninsulin-dependent type-II diabetes mellitus. Annu. Rev. Med. 47: 509-531.

Kato, H., Faria, T.N., Stannard, B., Roberts, Jr., C.T., and Le Roith, D. 1993. Role of tyrosine kinase activity in signal transduction by the insulin-like growth factor-I (IGF-I) receptor. Characterization of kinase-deficient IGF-I receptors and the action of an IGF-I-mimetic antibody ( $\alpha$ IR-3). J. Biol. Chem. 268: 2655-2661.

Katz, E.B., Stenbit, A.E., Hatton, K., DePinho, R., and Charron, M.J. 1995. Cardiac and adipose tissue abnormalities but not diabetes in mice deficient in GLUT4. Nature 377: 151-155.

Kim, J.K., Michael, M.D., Previs, S.F., Peroni, O.D., MauvaisJarvis, F., Neschen, S., Kahn, B.B., Kahn, C.R., and Shulman, G.I. 2000. Redistribution of substrates to adipose tissue pro- motes obesity in mice with selective insulin resistance in muscle. J. Clin. Invest. 105: 1791-1797.

Kolaczynski, J.W. and Caro, J.F. 1994. Insulin-like growth factor-1 therapy in diabetes: Physiologic basis, clinical benefits, and risks. Ann. Intern. Med. 120: 47-55.

Kulkarni, R.N., Bruning, J.C., Winnay, J.N., Postic, C., Magnuson, M.A., and Kahn, C.R. 1999. Tissue-specific knockout of the insulin receptor in pancreatic $\beta$ cells creates an insulin secretory defect similar to that in type 2 diabetes. Cell 96: 329-339.

Lauro, D., Kido, Y., Castle, A.L., Zarnowski, M.J., Hayashi, H., Ebina, Y., and Accili, D. 1998. Impaired glucose tolerance in mice with a targeted impairment of insulin action in muscle and adipose tissue. Nat. Genet. 20: 294-298.

Lauro, D., Kido, Y., Hayashi, H., Ebina, Y., and Accili, D. 1999. Expression of kinase-inactive mutant insulin receptors does not rescue insulin receptor-deficient mice from perinatal death. Diabetologia 42: 1441-1442.

Le Roith, D., Werner, H., Beitner-Johnson, D., and Roberts, Jr., C.T. 1995. Molecular and cellular aspects of the insulin-like growth factor I receptor. Endocr. Rev. 16: 143-163.

Lillioja, S., Mott, D.M., Spraul, M., Ferraro, R., Foley, J.E., Ravussin, E., Knowler, W.C., Bennett, P.H., and Bogardus, C. 1993. Insulin resistance and insulin secretory dysfunction as precursors of non-insulin-dependent diabetes mellitus. Prospective studies of Pima Indians. N. Engl. J. Med. 329: 19881992.

Michael, M.D., Kulkarni, R.N., Postic, C., Previs, S.F., Shulman, G.I., Magnuson, M.A., and Kahn, C.R. 2000. Loss of insulin signaling in hepatocytes leads to severe insulin resistance and progressive hepatic dysfunction. Mol. Cell 6: 87-97.

Moxham, C.P. and Jacobs, S. 1992. Insulin/IGF-I receptor hybrids: A mechanism for increasing receptor diversity. J. Cell Biochem. 48: 136-140.

Ota, A., Shen-Orr, Z., Roberts, Jr., C.T., and Le Roith, D. 1989. TPA-induced neurite formation in a neuroblastoma cell line SH-SY5Y is associated with increased IGF-I receptor mRNA and binding. Brain Res. Mol. Brain Res. 6: 69-76.

Shulman, G.I., Rothman, D.L., Jue, T., Stein, P., DeFronzo, R.A., and Shulman, R.G. 1990. Quantitation of muscle glycogen synthesis in normal subjects and subjects with non-insulindependent diabetes by $13 \mathrm{C}$ nuclear magnetic resonance spectroscopy. N. Engl. J. Med. 322: 223-228.

Wojtaszewski, J.F., Higaki, Y., Hirshman, M.F., Michael, M.D., Dufresne, S.D., Kahn, C.R., and Goodyear, L.J. 1999. Exercise modulates postreceptor insulin signaling and glucose transport in muscle-specific insulin receptor knockout mice. J. Clin. Invest. 104: 1257-1264.

Yakar, S., Liu, J.L., Stannard, B., Butler, A., Accili, D., Sauer, B., and Le Roith, D. 1999. Normal growth and development in the absence of hepatic insulin-like growth factor I. Proc. Natl. Acad. Sci. 96: 7324-7329.

Zisman, A., Peroni, O.D., Abel, E.D., Michael, M.D., MauvaisJarvis, F., Lowell, B.B., Wojtaszewski, J.F., Hirshman, M.F., Virkamaki, A., Goodyear, L.J., et al. 2000. Targeted disruption of the glucose transporter 4 selectively in muscle causes insulin resistance and glucose intolerance. Nat. Med. 6: 924928. 


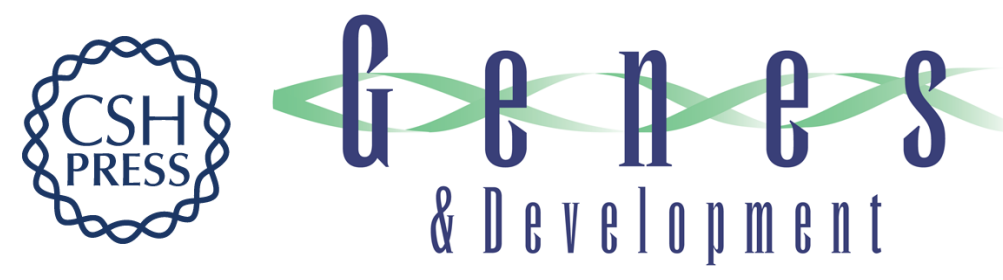

\section{Functional inactivation of the IGF-I and insulin receptors in skeletal muscle causes type 2 diabetes}

Ana M. Fernández, Jason K. Kim, Shoshana Yakar, et al.

Genes Dev. 2001, 15:

Access the most recent version at doi:10.1101/gad.908001

References This article cites 30 articles, 7 of which can be accessed free at: http://genesdev.cshlp.org/content/15/15/1926.full.html\#ref-list-1

License

Email Alerting

Receive free email alerts when new articles cite this article - sign up in the box at the top Service right corner of the article or click here.

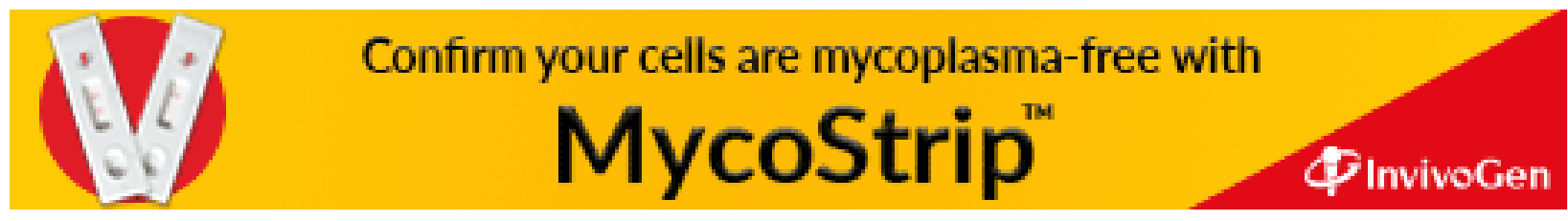

